\title{
Grandparents Raising Grandchildren: Financial Assistance ${ }^{1}$
}

Maisie Ross, Larry Forthun, Millie Ferrer-Chancy, and Angela Falcone ${ }^{2}$

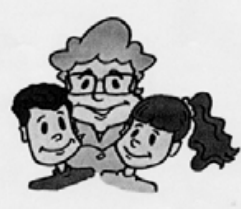

Goal: To provide information about financial assistance that is available in the state of Florida for grandfamilies.

It is often difficult to house, feed, and clothe an added individual to the family. This is more difficult when you are on a limited income. You and your grandchildren may be entitled to receive financial assistance. Listed below are several of these programs.

\section{Cash Assistance}

\section{Temporary Cash Assistance (TCA)}

This program, also called Temporary Assistance to Needy Families (TANF), offers cash assistance for low-income families. There are different rules for receiving cash assistance, but eligibility is determined by residency, income, and assets. You may qualify to receive benefits as a family, or your grandchildren can receive benefits under the child only grant. With the child only grant, your grandchildren may be able to receive benefits until they are 18 (or 19 if they are still in high school). Cash assistance is limited to a lifetime total of 48 months.

Need more information about TCA/TANF?

Access Florida

http://www.myflorida.com/accessflorida/ 1-866-762-2237 (TTY 711)

\section{TCA-Relative Caregiver Program}

This program provides monthly cash assistance and benefits for children living with relative caregivers. The amount of cash assistance depends upon the age of your grandchild. Payments are slightly higher than TCA. To qualify for this program:

- You must live in the State of Florida.

- You must have custody of your grandchildren; they were placed with you by a Florida court and the Department of Children and Families (or contracted provider).

- Your grandchildren must be younger than 18 .

- You must agree to a background check and home study completed by the Department of Children and Families (or contracted provider).

- You must cooperate with child support enforcement.

Need more information about the TCA-Relative Caregiver Program?

Access Florida

http://www.myflorida.com/accessflorida/ 1-866-762-2237 (TTY 711)

\section{Supplemental Security Income (SSI)}

This program pays monthly cash benefits to families with mentally or physically disabled children. To qualify, families need to have a limited income.

Need more information about SSI?

Social Security Office Locator https://secure.ssa.gov/apps6z/FOLO/fo001.jsp 1-800-772-1213 (TTY: 1-800-325-0778).

1. This document, adapted from the December 2002 version of FCS2188, is FCS2188a, one of a series of the Department of Family, Youth and Community Sciences, Florida Cooperative Extension Service, Institute of Food and Agricultural Sciences (IFAS), University of Florida. Publication date: August 2009. Please visit the EDIS Web site at http://edis.ifas.ufl.edu.

2. Maisie Ross, Family and Consumer Sciences, West Palm Beach County Extension, 559 N. Military Trail, West Palm Beach, 33415; Larry F. Forthun, Ph.D., assistant professor, Department of Family, Youth and Community Sciences, Institute of Food and Agricultural Sciences, University of Florida, Gainesville, FL 32611; Millie Ferrer-Chancy, Ph.D., interim dean, Florida Cooperative Extension Service, University of Florida; and, Angela Falcone, former FYCS graduate student of University of Florida. 
FOOD AND NUTRITION ASSISTANCE

\section{Food Stamps}

The Food Stamp Program helps limited-income families pay for food. When a family applies, this program considers...

- the total monthly household income of each adult,

- the value of items owned (not including your house), and

- $\quad$ other family expenses.

Need more information about Food Stamps?

Access Florida http://www.myflorida.com/accessflorida/ 1-866-762-2237 (TTY 711)

\section{Supplemental Program for Women, Infants, and Children (WIC)}

WIC provides monthly food checks that can be used to purchase foods that improve the nutritional quality of a child's diet. The types of foods you can purchase may vary, but can include: cereal, milk, eggs, cheese, juice, and beans. Your grandchild must be under the age of 5 to qualify. There are income requirements to receive WIC, but if your family qualifies for Medicaid, Food Stamps, and TAC, you will very likely qualify for WIC. To apply for WIC, you will need to prove legal custody or guardianship of your grandchildren.

Need more information about WIC?

Florida WIC

http://www.floridawic.org/

1-800-342-3556

\section{ENERGY ASSISTANCE}

\section{Low-Income Energy Assistance Program}

This program provides money to local governments to assist low-income families with home heating and cooling costs. Eligibility is determined by the local agency; however, you may be eligible if you are currently receiving the following assistance:

- Supplemental Security Income (SSI)

- Food Stamps

Need more information about energy assistance?

Florida Department of Community Affairs http://www.dca.state.fl.us/fhcd/liheap/index.cfm

\section{Child Care Assistance}

\section{School Readiness Program}

Coping with the demands of caring for children on a daily basis can be very stressful. You may need to work at the same time you are caring for your grandchild. The Florida Agency for Workforce Innovation, Office of Early Learning provides financial assistance to low income families for childcare services. Childcare services include extendedday, extended-year, and school age care. Eligibility requirements vary by county.

Need more information about the School Readiness Program?

Agency for Workforce Innovation

School Readiness Program http://www.floridajobs.org/earlylearning/ sr programs.html

1-866-357-3239

\section{Head Start/Early Head Start}

These are programs for children from birth to age five. They are child-focused programs aimed at increasing the school readiness of young children in low-income families.

Need more information about Head Start/Early Head Start?

Florida Head Start http://www.floridaheadstart.org/

\section{TAX CREDITS}

\section{Earned Income Tax Credit (EITC)}

You may qualify for EITC if you meet all of these criteria:

- Your grandchild is under age 19 or under age 24 and is a full-time student

- Your grandchild has lived in your home for more than 6 months of the tax year.

- You pay more than $50 \%$ of your grandchild's support and the child is not claimed as a dependent by the parent

- You have worked during the tax year

Need more information about the Earned Income Tax Credit?

Internal Revenue Service (IRS)

1-800-829-1040

\section{OTHER RESOURCES}

The National Council on Aging sponsors a Web site called Benefits Checkup. It is designed to help you find local resources and benefits for a variety of needs (cash, food, housing, medical, and more). The process usually takes about 20-30 minutes. The Benefits Checkup Web site is accessible at the following URL:

https://www.benefitscheckup.org/ 